\title{
Monstrous Aunties: The Rabelaisian older Asian woman in British cinema and television comedy
}

Estella Tincknell, University of the West of England

\section{Introduction}

Representations of older women of South Asian heritage in British cinema and television are limited in number and frequently confined to non-prestigious genres such as soap opera. Too often, such depictions do little more than reiterate familiar stereotypes of the subordinate 'Asian wife' or stage the discursive tensions around female submission and male tyranny supposedly characteristic of subcontinent identities. Such marginalisation is compounded in the relative neglect of screen representations of Asian identities generally, and of female and older Asian experiences specifically, within the fields of Film and Media analysis. These representations have only recently begun to be explored in more nuanced ways that acknowledge the complexity of colonial and post-colonial discoursesi. The decoupling of the relationship between Asian and Indian, Pakistani and Bangladeshi heritage, together with the foregrounding of religious rather than national-colonial identities, has further rendered the topic more complex.

Yet there is an exception to this tendency. In the 1990s, British comedy films and TV shows began to carve out a space in which transgressive representations of aging Asian women appeared. From the subversively mischievous Pushpa (Zohra Segal) in Gurinder Chadha's debut feature, Bhaji on the Beach (1993), to the bickering 'competitive mothers' of the ground-breaking sketch show, Goodness, Gracious Me (BBC 1998 - 2001, 2015), together 
with the sexually-fixated grandmother, Ummi (Meera Syal), in The Kumars at Number 42 (BBC, 2001-6; Sky, 2014), a range of comic older female figures have overturned conventional discourses. Here, the dominant tropes of ageing Asian femininity are those of the carnivalesque and the grotesque rather than the submissive and repressed. The confined and conventional Indian 'Auntie' is thus transformed into a Rabelaisian figure of excess - a 'jester' whose ritualistic violations of gendered and aging norms through 'clownishness' forces laughter in response.

It should be noted that older women have long tended to be represented in limited and archetypical ways within British popular culture and situation comedy: as domineering battleaxes (e.g. Nora Batty in Last of the Summer Wine, BBC, 1973 - 2010; Mrs Slocombe in Are You Being Served, BBC, 1972 - 1985); as put upon but supportive wives (e.g. June in Terry and June, BBC, 1979 - 1987); and as sexually predatory and therefore threatening divorcees or 'semi-detached' married women (e.g. Dorien in Birds of a Feather, BBC, 1989 1998, ITV, 2014 - 2017). Indeed, these archetypes constitute the totality of the three main female characters in the current sitcom Two Doors Down (BBC, 2013 -). In contrast, Bollywood cinema has consistently made space for a range of older women characters in its depiction of the extended family and broad kinship networks. My interest, however, lies in the intersectional relationships between British popular culture and comedy, British-Asian and diasporic identities, and the forging of new and potentially subversive tropes of ageing femininity. Arising from research as part of the Women, Ageing, Media network, my work is situated within the interventions made by WAM into the politics of representation and the politics of ageing. 
This essay draws on the work of Bakhtin to consider the extent to which such representations can be considered genuinely subversive, especially within the cultural and institutional contexts of the racist depictions and liberal humanist discourses around gender, race and age which have shaped British film and television cultures. My approach also recognises the potentially contested nature of the term 'Asian', particularly since the 9/11 attacks, and its specific application within a British cultural context in which the history of post-war immigration to the UK helped to construct new kinds of identities and ethnocultural affiliations.

\section{Everybody's Auntie: Older women in sub-continent popular cultures}

The terms 'Auntie' and 'Uncle' are widely used within sub-continent and diasporic Asian cultures as generic honorifics to describe middle-aged or older non-family members as well as those in the extended family. Every older female is 'Auntie' even when she is only remotely related to the speaker. The Asian Auntie is, then, a universal figure, omnipresent in extended family networks and quasi-familial relations. Aunties are both benign and potentially dangerous, subject to mockery and condescension but also respected and feared by younger people. They dispense advice, spread gossip, proffer wisdom, and endear and annoy in equal measure. Described by the NDTV website devoted to Indian popular culture as 'omnipotent and omnipresent', Aunties can be frumpy, grumpy and repressive or liberating and liberal. ${ }^{\mathrm{i}}$ 
Aunties are also a central component of Bollywood cinema partly through its focus on rituals and celebrations involving the extended family; they may act as a chorus (of approval or disapproval), commenting on the romantic and family relationships that are the foregrounded subject matter, or they may be more active supporters or conspirators, working to help the romantic couple or to separate them iii. There are websites dedicated to variations of Bollywood Aunties ('Flirty Auntie', 'Vampy Auntie')' male stars drag up as the eponymous older woman (e.g. Aunty No 1, Kiri Kumar, 1998), while 'Shammi Aunty' was the affectionate nickname bestowed on the character actress, Nargis Rabardi, who appeared in numerous Bollywood films and television sitcoms in this role. $^{\vee}$ Above all, Aunties carry both a degree of cultural authority and the potential to have that authority challenged as incipiently monstrous personages, whose power can be temporarily punctured by ridicule but is never wholly destroyed.

Indeed, because the Auntie is such a culturally loaded figure her Rabelaisian potential becomes pressing, given the power relations of contemporary discourses around age, gender and ethnicity. Furthermore, the proposal that Aunties are 'omnipotent' is an overdetermination. Such powers that Aunties possess are themselves framed within a deeply patriarchal culture in which older middle-class Asian women remain largely domestically sited; their right to judge and to intervene is contingent on their position within the private realm of the extended family not the public sphere.

As with the tradition of British 'low comedy' and its organisation of women into 'battleaxes', 'blondes', 'birds' and 'bitches', vi the bodily grotesque can be a key feature of the way Aunties are represented. Where one version of the Auntie may be a regulatory figure, 
wagging a sometimes metaphorical finger at the behaviour of different classes, castes, or individuals, a second version is of the Auntie whose own suppressed desires are expressed through a carnivalesque excess of eating, drinking or dancingvii. As Mikhail Bakhtin argues, the tradition of grotesque images of feasting, violence, and 'the material lower bodily stratum' found in folk and popular cultures expresses a reversal of social expectations and social order. Indeed, nothing is fixed in Bakhtin's carnival world, and everything is in a state of becoming. 'Official' culture is subverted by laughter, and overturned. Authority figures are challenged, bodies rendered ridiculous, 'the world is seen anew, no less (and perhaps more) profoundly than when seen from the serious standpoint' (Bakhtin 1968, 66).

The contradictory potential of Aunties as the moral guardians of social norms whose own desires, once unleashed, precipitate social breakdown is therefore crucial. Their cultural and moral authority seems (within western discourses certainly) to transgress the stereotypical conventions of Asian patriarchy, while their bodily presence throughout South Asian culture confounds the western marginalisation of aging femininity. And, as Jane Arthurs $(1995,63)$ and others have pointed out in the context of the 'unruly woman' and especially the unruly older woman in British comedy, 'the potent mix of disgust and desire produced by the transgression of bodily decorum...offer[s] a "licenced space" for the expression of these desires.' It is this licence and its comic potential to subvert or challenge conventional hierarchies that I will explore here.

\section{From the Margins: Asian women in British cinema}

Until the 1980s there was very little Asian presence in British made films or television programmes other than in the form of exoticised background figures. While the 1930s had 
seen the appearance of India's first international male movie star in the form of the child actor, Sabu, who was cast in Zoltan Korda's British-made but India-set Elephant Boy in 1937 and went on to play other similar parts in The Drum (1938) and The Thief of Baghdad (1940), this did not set a precedent nor did it clear space for a wide range of representations. Sabu was an exception; a contradictory figure who was simultaneously non-threatening and nonsexual because of his child status and therefore acceptable within the Imperialist cinematic tradition, yet who was also subject to the orientalist homoerotics of 1940s Hollywood. viii

Made between the early 1930s and the 1950s, these imperial epics, as Jeffrey Richards (1983) calls them, were primarily intended as propagandist texts in which 'British' virtues of courage and self-sacrifice were deployed in the service of the Empire, and native Indian leaders, when they appeared at all, were depicted as despotic tyrants. In such films, South Asian women were far from the narrative focus, were confined to roles as 'local colour' and were in any case usually played by white actresses ${ }^{\mathrm{ix}}$. Characteristically, in the one film of the period to feature an Indian female character in a named role, Black Narcissus (1947), Michael Powell and Emeric Pressburger cast the English actress Jean Simmons as the 'local temptress', the 'luscious' Kanchi, thus compounding the racial stereotype with exclusionary casting practices ${ }^{\mathrm{x}}$.

During the 1950 s and 1960 s, commonwealth immigration to the UK, initially encouraged by successive British governments, meant the arrival of Asians from across the Indian subcontinent, but especially the Punjab, Pakistan and (after 1971) Bangladesh, settling primarily in London, Birmingham and other major industrial cities to work in factories, mills and workshops, or as doctors and nurses in the newly established NHS. This post-war 
immigration was followed in the 1970s by the arrival of East African Asians as a

consequence of the expulsion of Asians from Kenya and Uganda, many of whom were highly successful business people ${ }^{x i}$. These waves of migration not only had a profound impact on British society and the economy, they would help to transform British identity and culture. They also ensured that Asian actors were now available to play Asian roles within British production contexts, although this did not always mean they were cast.

Carry On Up the Khyber (1968), for example, features two leading Indian characters, the Khasi of Kalabar and Princess Jelhi, played respectively by the white Carry On 'regular' Kenneth Williams and the equally fair ingénue Angela Douglas ${ }^{\mathrm{xii}}$. Indeed, the film presents a cornucopia of casual orientalism, levering in harems, belly-dancers, snake charmers and yogis, in a parade of British popular cultural stereotypes that conflates and confuses cultural, religious and ethnic differences.

This tendency marked many attempts to represent Asian characters during the 1970s. Most notoriously, the casting of the India-born but decidedly white actor, Michael Bates as an Indian bearer, Rangi Ram, in the Burmese-set comedy focused on a wartime concert party, It Ain't Half Hot Mum (BBC, 1974 - 81), has become emblematic of British television's racist heritage $^{\text {xiii. }}$ While the programme also did not feature women other than in occasional parts, it certainly offered aspects of Bakhtinian excess in the concert party's use of drag, which seemed to be implicitly connected to its discursive emphasis on the dangers of a feminised tropical heat for 'civilised 'western bodies and desires. 
In contrast, Mind Your Language (LWT, 1977-86), located its 'others' back in Blighty. Set in a London Further Education College English language class, and featuring perhaps the most egregious parade of racial stereotypes ever gathered together in a single television programme (the 'sexy' French woman, the hard-working German, the polite Japanese and so forth), it did at least include an older Asian woman amongst this melange, Jameela Ranjha (Jamila Massey). Jameela is typecast as an 'Indian housewife' (of uncertain and fluctuating religious and cultural affiliation), and her characterisation within a show framed by the conventions of the institutional sitcom offers disappointingly limited potential for a Bakhtinian reading ${ }^{\mathrm{xiv}}$. While other characters inhabit the Rabelaisian universe to some degree or another, portraying different kinds of carnivalesque behaviours, the portrayal of Jameela is distinctively constrained, as though the programme were afraid to permit her to transcend the established conventions of the ideal Indian housewife.

Notwithstanding these (very limited) examples, until the 1980s the only regular appearance of older Asian women was to be found on BBC television's topical weekly Sunday morning show aimed at new immigrants to the UK, Nai Zindagi, Naya Jeevan ('New Life' in Urdu and Hindi; BBC, 1968 -82) which, as Rupa Huq notes, featured 'classical Indian music fronted by stern Asian uncle- and aunty-like presenters' $(2013,78)$. This programme was clearly intended to 'educate and inform' rather than entertain its Asian audience, who were presumed to be in need of advice on how to thrive in their new homeland. However, its Sunday scheduled timeslot reflected its marginalised cultural location.

A final and extremely important exception to the prevailing cultural stereotypes during this period was the Birmingham-set television series, Gangsters (BBC, 1975, 1976 - 78), which 
was the first to feature an Asian character in a leading role, the charismatic detective Khan (Ahmed Khalil) ${ }^{\mathrm{xv}}$. Although formally ground-breaking as well as culturally innovatory, its criminal underworld milieu excluded female characters other than the most hackneyed of archetypes and certainly failed to make space for older women.

\section{The 'multicultural turn' and transgressive potential}

A wider range of representations of South Asian experience across both cinema and television in Britain only really began to manifest in the 1980 s, due to the combined pressures of a second generation of Asian Britons, a more articulated form of left identity politics which found voice in an emergent independent media, and the arrival of Channel 4 and its film production offshoot, Film Four. The latter, because of its commitment to smallscale, non-standard projects, facilitated the growth of experimental and oppositional filmmaking, and also offered opportunities for aspiring directors and writers from ethnic minority backgrounds as well as women. Gurinder Chadha (of whom more later), for example, made her first film, a documentary about second generation Asian Britons, I'm British, But... (1989), with backing from Film Four. The appearance of her work and that of others such as Pratibha Parma thus seemed to mark a 'multicultural turn' in British media production.

While the most critically approved of these texts was Hanif Kureishi and Stephen Frears's My Beautiful Laundrette (1985), it is notable that this film shows little interest in presenting unconventional depictions of older Asian women: they are entirely confined to the domestic margins as homosocial relationships are privileged. Instead, period drama became the 
space in which stereotypical depictions of Asian women slowly began to be enriched by greater complexity and nuance and older women began to be more fully realised. The appearance of the nostalgia-tinged 'Raj revival' cycle of texts, including the film Heat and Dust (1983) and the television series The Jewel in the Crown (Granada 1984), set in British ruled India, alongside the ostensibly more radical films produced for Film Four is perhaps characteristic, not only of the cultural polarisation Thatcherism engendered during this decade, but also of the way in which transgressive representations took unexpected forms.

Based on Paul Scott's 'Raj Quartet' of novels set in India at the moment of the fight for independence from British rule and published between 1965 and 1975, The Jewel in the Crown may be seen with hindsight as in some ways a more important cultural landmark than Laundrette. Not only did it reach a much wider audience than Frears's film, its ambition was more complex, even if the process of adaptation and its cinematic production values veiled its social critique in nostalgia.

Crucially, it featured Zohra Segal as Lady Lili Chatterjee, a proud Bengali noblewoman (and the widow of an industrialist knighted for his founding of Mayapore Technical College), a leader of Indian society in Mayapore, whose wealth enables her to mix freely across the Anglo-Indian divide ${ }^{x v i}$. Lady Chatterjee confounds a number of stereotypes of Asian women: she is old and not particularly glamorous or beautiful; she is neither submissive to men nor domestically-focused; and she engages with the British as a social equal not a subordinate.

However, the television dramatization offered significantly less narrative space to the character than Scott's original novel in which she plays a pivotal role. Instead, Lady 
Chatterjee's narrative agency is transferred onto a white character and she appears as a colourful secondary figure in the television version, appearing in just two episodes, rather than as a key player in the unfolding events of the story. Importantly, too, it seems plausible that the respect afforded the character is linked to her class position. As I have noted elsewhere, television and film are considerably more respectful of older women when they are aristocrats or members of the upper classes (see Downton Abbey, ITV 2012 -16), and this seems to have superseded the problem of Lady Chatterjee's race. xvii

Nonetheless, the discursive space cleared for the character of Lady Chatterjee alongside other Indians in the drama represented a significant shift ${ }^{x v i i}$. The Jewel in the Crown became the most celebrated and talked about television series of the early 1980s, an example of 'event TV' that was also serious-minded in its depiction of the political turmoil engendered by the end of Empire and the complex interplay of identity, culture, nationhood and race that it entailed. As such, the programme reflected emergent changes in the way British popular culture and media negotiated the relationships between whiteness and 'otherness', and increasingly attempted to incorporate Asian characters and experiences. Of course, such interventions were also often limited, and laced with the burden of representation whereby Asian characters (like their Black counterparts) were required to stand for their race rather than embodying the full range of human experience ${ }^{\mathrm{xix}}$. Nonetheless, they heralded an important shift in the prevailing cultural atmosphere.

I would argue that these changes were prefigured in a genre that may have seemed unlikely at the time but now makes cultural sense. A television cookery show, Madhur Jaffrey's Indian Cookery (BBC 1982), in which a sari-clad Jaffrey demonstrated how to make Rogan 
Josh to an audience presumed to be entirely white but for whom the local tandoori restaurant had begun to unlock new cultural possibilities, marked the extent to which some aspects of Asian culture had, by the early 1980s, begun to be integrated into British life. Crucially, Jaffrey was very far from the comedy housewife figure of Mind Your Language or the subservient and self-effacing Indian women of Imperialist myths; she was authoritative, sophisticated and confident.

The show and its accompanying book offered a career departure for Jaffrey who had been a professional actress from a wealthy, cosmopolitan family rather than a professional housewife (and whose middle-class background meant that she did not learn to cook until she moved to London, aged 19). Its success meant Jaffrey went on to make further series and publish a number of popular cookery books. ${ }^{x x}$ It also opened the door to other 'ethnic' cookery shows (such as Ken Hom's Chinese Cookery, BBC 1984) that reflected the increasing diversity and cultural complexity of British society. By foregrounding food such shows made cultural change almost literally palatable to audiences, and heralded the arrival of television multiculturalism.

However, arguably the most significant television intervention into cultural diversity was the BBC's decision to regularly include an Asian couple, Saeed and Naima Jeffery (Andrew Johnson and Shreela Ghosh) in its new landmark soap opera, East Enders, which began its run in 1985. The soap imperative to 'reflect reality' by acknowledging the presence of Asians within traditionally white working-class communities thus expanded the discursive possibilities. Admittedly, the characters were largely confined to a stereotypical set of narrative relationships, as the corner shop entrepreneurs battling tensions over 'western' 
versus 'traditional' values, and the subordination of Asian women to a supposedly excessively dominant patriarchal structure. Memorable older female characters were largely absent from storylines, too, until the introduction of Zainab Masood (Nina Wadia) in 2007, and have rarely been permitted the comic dimensions found in some of their white counterparts. Indeed, the show tended to present Asian characters within a western-style nuclear family context rather than the more authentic extended family model that would have permitted a wider range (and age range) of female characters, including the odd Auntie.

Finally, Tandoori Nights (Channel 4, 1985-87), was Channel 4's first foray into an Asianbased situation comedy and starred Saeed Jaffrey, apparently reprising his role from $M y$ Beautiful Launderette, as the owner of one of two rival Indian restaurants in London's Brick Lane $\mathrm{xxi}^{\mathrm{x}}$ In keeping with the channel's remit, the show attempted to overturn racial stereotypes, but did so by largely reinforcing gendered ones. It also featured the increasingly ubiquitous Zohra Segal as a mischievous elderly woman. However, as Shalini Chandha (2018, no page numbers) points out, 'unfortunately Tandoori Nights suffered from a comedic deficit - though the fact that it gave rare opportunities to Asian talent behind and in front of the camera is, one can argue, distinction enough.'

\section{Transgressive pleasures}

In contrast, Gurinder Chadha's two major British-set feature films, Bhaji on the Beach (1993) and Bend it Like Beckham (2000), were both genuinely funny. Both also represented significant interventions into conventionalised norms around aging, gender, ethnicity and culture. The first, co-written with Meera Syal who, like Chadha, has made an impressive 
contribution to British comedy, was the first UK-made feature film to depict a broad range of British Asian female characters in a way that did not reduce them to a social type. Set in Syal's native West Midlands and then Blackpool, that most carnivalesque seaside resort, the film tells the story of a group of Asian British women of Punjabi Sikh and Hindu heritage on a day trip to see the famous Illuminations. The broad range of characters of different ages, backgrounds and dispositions, together with the story's blend of observational humour and drama, meant that Bhaji on the Beach fitted into the British tradition of social realist comedy while foregrounding the problematics of contemporary racial identities and gender relations. As Mendes (2010, passim) points out, Chadha's own transnational, hybrid identity is central to her critical engagement with both 'western' and 'Asian' narrative traditions. ${ }^{x x i i}$

The film features three potential Auntie figures: Aasha (Lalita Ahmed), a dutiful housewife whose fears about the conflict between the 'traditional' imperatives of Hindu culture and the 'modern' expectations of western life are initially played out in a Bollywood-style dream sequence; Rekha (Souad Faress), a Bombay-based cousin who has followed her negligent husband to the UK on a whim and, equally whimsically, ends up on the Blackpool trip; and the elderly Pushpa. While the depiction of Rekha's cosmopolitan attitudes clearly seeks to subvert the norms surrounding the depiction of middle-aged Indian women in British media at the end of the 1980s, the character is insufficiently developed for comedic effect to make her a true Auntie figure.

Perhaps the most potentially transgressive figure, then, is the elderly Pushpa, played (once again) by Zohra Segal. Beginning, in true Auntie fashion, as the guardian of traditional sexual morality, and condemnatory when she accidentally discovers that college-bound 
Hashidi (Sarita Khashuria) is pregnant by her Black British boyfriend, Oliver (Mo Sesay), Pushpa later engages enthusiastically with the pleasures of the British seaside: she eats chips from a paper parcel (liberally spiced) on the seafront, and plays bingo in an amusement arcade. The Bakhtinian possibilities of Blackpool are fully realised towards the end of the film at the Manhattan Cocktail Bar, however. Here, a group of male strippers dressed in military whites pulls Pushpa into their midst and forces her to dance with them as they gyrate for their female audience. At this moment Pushpa finally discards her initial repressiveness and rigidity to embrace the bodily pleasures of dance.

Chadha's ninth film, Bend it Like Beckham, was given a wider release and proved to be a breakthrough opportunity for its stars, Parminder Nagra (as the Sikh 'Jess' Bhamra) and Keira Knightley (as the white 'Jules' Paxton), playing two aspiring young Hounslow footballers. xxiii The film's focus on the struggles each faces to be taken seriously as a footballer skilfully foregrounds the different but equally problematic ways in which patriarchy, sexism, and gendered expectations shape their lives. Older women in the film are largely contained by different kinds of domesticity and here cultural differences between 'western freedom' and 'eastern restriction' are deliberately shown to be superficial. Jules's narrow-minded social-climbing mother, Paula (Juliet Stevenson) is depicted as profoundly conservative in her aspirations for her daughter; terrified that the friendship with Jess is a lesbian affair, she is incapable of recognising that Jules might have a social role beyond her exchange value as a bride.

It is in the wider context of the extended family that Bend It Like Beckham foregrounds the more specific centrality of Aunties to Asian (and here specifically Sikh) culture. Jess's sister 
(Archie Panjabi) and her fiance (Trey Farley) celebrate their engagement with a family party in which numerous relatives crowd the already cluttered family sitting room. Aunties, initially seen in the centre of the shot and at the heart of the family seated in a row on the sofa, line up to congratulate the happy couple and bestow approval on their forthcoming nuptials. At the very centre is Zohra Segal, Auntie-in-chief, although here in an unnamed role, beaming in delight. Later, at the wedding both Aunties and Uncles are depicted thronging the banqueting hall for the celebrations, as a Bhangra band sets the beat for dancing. One Auntie, hitherto swaying slightly to the music in a suitably dignified manner, is swept up by her excited husband who lifts her above his shoulders and promptly buries his face in her ample bosom. Even Aunties (and Uncles) let their hair down sometimes.

\section{And bodily grotesques...}

Important though Chadha's work has been to establishing British-Asian cultural identities in contemporary cinema, I would argue that the most significant, if less prestigious, intervention into representations of older Asian female identity in British popular culture and comedy is probably that made by The Kumars at Number 42, a hybrid sitcom-chat show that followed in the wake of the break-out success of Goodness, Gracious Me in the 1990s. Originally screened on BBC television between 1998 and 2001, the latter had been the first British comedy show to feature an all-Asian cast and, perhaps more importantly, an all British-Asian cast who were also the writers: Meera Syal, Sanjeev Bhaskar, Nina Wadia and Kulvinder Ghir. It also broke ground by presenting characters and sketches which mocked the British Asian experience without seeking to 'explain' Asian culture to a white audience ${ }^{\text {xiv }}$. Its title - a knowing reference to a musical duet from 1960 by Sophia Loren and Peter Sellers in 'comedy Indian' mode here revamped as a Bhangra number xxv_ 
indicated that attitudes to Asian stereotypes had sufficiently relaxed by the late 1990s to permit their parody.

Although the most celebrated sketch is 'Going for an English', which mocked the way the Friday night curry had become a cultural ritual in the UK in the late 1990s, the programme also regularly featured a number of transgressive older female characters, all played by Wadia and Syal. These included the self-deluded 'Showbiz Reporter' Smeeta Smitten, and the ostensibly respectable 'competitive mothers'; two housewives whose encounters invariably become an opportunity to indulge in a hostile exchange concerning the sexual prowess of their male offspring involving an ever-increasing spiral of linguistic and Freudian excess.

One character, played by Wadia and supposedly based in part on her own mother, "Mrs. I could make it at home for nothing", is shown responding to various dilemmas with the simple riposte that she could provide the same goods or services at home with no cost other than that of a "small aubergine". The character clearly draws, sometimes very poignantly, on the Asian migrant experience. Indeed, her extreme abjection itself constitutes a form of carnivalesque performance: as with the tradition of melodrama, female subservience is rendered so pathetic that the underlying power relations of dominance and subordination are revealed.

The programme was not recommissioned after 2001 but returned for two 'reunion' one-off shows in 2015 to mark the 60th anniversary of BBC2. This reappearance registered the programme's popularity, and was also in part an official acknowledgement by the BBC of its 
canonical status as signifier of an increasingly intersectional British national identity and hybridised comedy culture.

Despite its cancellation, the popular success of Goodness, Gracious Me led to a follow-up comedy show, The Kumars at Number 42 (BBC 2001 - 5, Sky, 2014 -), also starring Meera Syal and Sanjeev Bhaskar. However, this was a more hybrid (and perhaps more potent) mix of domestic sitcom and chat show. Set in the fictional and comfortably middle class Wembley home of the Kumar family, it starred Bhaskar as Sanjeev, the indulged grown-up son of Madhuri and Ashwin Kumar (Indira Joshi and Vincent Ebrahim), who have supposedly built a television studio in their back garden so that he can host his own chat show.

The programme had real celebrity guests and a combination of scripted and improvised dialogue. Its blend of conventional sitcom tropes (the buffoonish older man, the indulgent mother figure, the spoilt son) and chat show parody meant The Kumars was both familiar and de-familiarising. The programme played with the generic conventions of both formats, gently subverting the mainstream British sitcom's bourgeois habitus while also deconstructing the absurdities of the celebrity interview. Its backstage/frontstage format meant that the invited guests were first treated to Indian hospitality in the 'family sitting room' and then ushered 'on stage' to the chat show set. Here they were subjected to Sanjeev's preening and the naïve questions of his mother and father, who were depicted as primarily interested in the most banal aspects of the celebrity's home life. In this way the programme challenged the sensationalism of celebrity gossip by emphasising the ordinariness of star guests rather than their extraordinary status (to paraphrase Richard Dyer's famous dictum) $)^{x \times v i}$. 
Yet the apparently cosy set-up concealed the extent to which The Kumars embraced the carnivalesque in even more extravagant ways than Goodness Gracious Me. The domestic setting and the blatantly absurd conceit of the self-financed chat show meant that the programme's genuinely radical edge was not immediately apparent. Yet guests were regularly insulted, ignored, ridiculed or subtly sent up, not only in the direct interview questions fired at them by Sanjeev and his family in a ritualised process of 'dethroning', but also in the way their celebrity status provoked obviously exaggerated pleasure or sometimes affected bafflement on the part of the hosts.

However, the most genuinely subversive element in the show was the family's grandmother, Ummi, played with mischievous glee by Syal as a leering, highly immodest, and thoroughly anarchic character - in other words, as the 'jester' at the court of 'King Sanjeev'. Ummi not only challenges masculine power by regularly interrupting and challenging her 'grandson' during his inept interviews, she makes frequent references to sex, using innuendo and suggestiveness to the male celebrities whom she alternately fawns over, physically mauls, and then abruptly ignores if another more famous face appears. She also farts, sits with her legs open rather than modestly closed, hogs the snacks that Sanjeev's 'mother' hands round and generally sets out to embarrass her relatives - because she can.

In this regard, Ummi is a thoroughly carnivalesque figure. Her bodily functions and desires are expressed rather than suppressed. She turns the world of the guests upside down with her frank questions, and speaks the unspeakable. She also attempts a 'free exchange' with 
guests on equal terms that are frequently disruptive. Her jester role enables her to undertake the 'ritualistic violation' of social etiquette concerning invited guests and the cultural norms of aging womanhood in which deference, docility and domestic labour are prioritised. The aging Asian woman might be expected to perform the role of grateful hostess, subordinating her own desires and actions to the wishes of her guests. Ummi, however, makes no such concessions.

For example, in an episode featuring the film and stage star Sir Patrick Stewart, in which he tells an anecdote about his father's background in the British Army in India and the latter's subsequently embarrassing behaviour towards waiters in Indian restaurants, she ripostes by saying, "Yes, we appreciate being insulted in our own language". Stewart is clearly somewhat taken aback by her forthright response, which effectively repudiates the conscience liberalism of his shame-faced telling of the story and demands something more than the easy acknowledgment of past racism. Here, the show's Rabelaisian tendencies overturn its apparent cosiness and its commitment to a sly transgressiveness becomes evident.

In two examples from 2003, this is even more powerful. The Christmas 2003 episode featured Sir Cliff Richard and repeatedly and knowingly referred to his previously unacknowledged mixed race background ("He came over here as an immigrant, got a council house and is now the King of Pop..."). Ummi determinedly clings onto Sir Cliff's arm as he enters the chat show studio and then leers fondly at him as Sanjeev questions the star about his Indian birth. "He's one of us" she crows gleefully as Sir Cliff shows off his Hindi, 
thus undermining the star's hitherto careful cultivation of the 'Anglo' side to his AngloIndian heritage.

In an episode featuring Madness in the same year, Ummi follows the group into the studio copying their 'nutty boy' swagger to such an extreme degree that she falls onto the sofa. She then proceeds to quiz them about relationships within the group. Having established that "it is just like a family" she throws in a barbed question referencing prison slang for the senior figure in an all-male hierarchy: "so, if it's like a family, who's the daddy?" Not only do the 'nutty boys' have no answer to this, their homosocial friendship structure is comically exposed by the apparent innocence of the question: who, indeed, is the 'daddy' in such allmale pop groups with that kind of longevity.

In a further episode, Ummi schmoozes up to the British actor Nigel Havers, well known for playing upper class charmers, and nestles into his arm clutching a Bellini cocktail, mixed in deference to his class position and the good taste it bestows. "You've got a very strong nose, haven't you?" she observes, "Is that the result of years of aristocratic in-breeding?" Havers gamely acknowledges that it is, to which she replies with a cackle, "all the better to sniff me with, eh..." This potential Bakhtinian misalliance, like each of those instigated by Ummi's 'out of place' sexual desires across the programme's other episodes (with the boyband, Westlife, with singer Elvis Costello, with "Geordie beefcake" actor Robson Green, whom she forces to play Strip Poker, and with Leslie Philips, the British character actor also famed for his smooth charm), is fortuitously interrupted by the arrival of Sanjeev and the ushering of Havers into the 'studio' for the chat show element to begin. 
In Ummi, the dominant tropes of aging Asian femininity are those of the carnivalesque and the grotesque rather than the submissive and repressed. The confined and conventional Indian Auntie is thus transformed into a Rabelaisian figure of excess. Ummi is granted the freedom conventionally assumed by all Aunties to comment on, challenge and undermine the behaviour and mores of younger members of the family, but here that freedom is taken to its comic extreme. Yet, because Ummi is an old woman, the celebrities are rendered offguard, silenced by her refusal to be docile, deferential or domesticated.

Having said this, I would like to briefly discuss a further final text from the cultural moment of the early noughties, largely in order to foreground the contrast between the womancentred comedy of The Kumars and a very different articulation of the carnivalesque. East Is East (1999) was the first internationally successful British comedy film by a British Asian writer, Ayub Khan-Din. Based in part on Khan-Din's childhood and originally a stage play, it tells the story of a British-Pakistani family living in Salford in 1971. Dominated by a stereotypically tyrannical Asian father, 'George' Khan (Om Puri), who runs a corner shop chippy and is seeking out suitable marriage partners for his children, the family is depicted as struggling to reconcile opposing 'western' and 'eastern' values, here constructed almost entirely in terms of sexual licence versus sexual constraint and focused on male entitlement to the former. The scatological and misogynist nature of much of the comedy makes women the butt of many jokes, especially Asian women.

Unlike the Rabelaisian freedom granted to the character of Ummi, older women characters here revert to the comedy archetypes noted at the beginning of this article, further inflected by racial discourses. They are represented as either long suffering but supportive if they are 
white or as repressive and alien if they are Asian, as in the disapproving potential mother-inlaw, Mrs Shah (Leena Dhingra), who visits the Khan family with two ugly daughters in tow. In this key scene, younger son Saleem (Chris Bisson) accidentally flings the grotesque sculpture of a vulva complete with pubic hair he has secretly modelled in his art class into the lap of the respectable Mrs Shah, who screams with alarm and then denounces the Khan family.

Widely celebrated as a moment of hilarious comedy, this sequence for me presents a much more disturbing articulation of the carnival as a moment of laddish misogyny, in which the possibilities for subversion opened up by The Kumars are closed off, reminding us of the carnival's limitations. Mrs Shah's horror is cast as a symptom of sexual repression and thus permits the film to put the Shah women 'back in their place' as harbingers of an oppressively restricted sexuality. Furthermore, the stream of abuse hurled after Mrs Shah and her daughters as they leave the house renders them utterly abject. Reframed by 'honest' British attitudes to sex (i.e. smut) the Asian women are, in fact, erased as human beings. Indeed, the sequence is something of a synecdoche. Ostensibly ground-breaking in its depictions, the film is much closer to the atmosphere of crude racism and sexism of some of the 1970s comedies discussed earlier. The fact that the text privileges youthful male desire at the expense of older women is symptomatic of its appearance at the high point of British 'lad culture' in the late 1990s, and also marks a moment of recuperation in which Aunties are firmly placed back in the mocked not mocking box ${ }^{x x v i i}$.

\section{Recuperations}


Indeed, while older Asian women have featured more centrally in recent narrative film and television texts this is often discursively managed by generic retrogression. For example, Citizen Khan (BBC, 2012 -) a Birmingham-set sitcom about the self-appointed 'community leader', Mr Khan (Adil Ray), his long-suffering wife, Razia (Shobu Kapoor), and two very different daughters, the dutiful Shazia (Maya Sondhi, Krupa Pattani) and the duplicitous Alia (Bhavna Limbachia), has been a significant popular success. The show has been accorded the accolade of a regular Christmas Special (an especially ironic yet pleasing gesture given that it is about a Muslim family) and Mr Khan has entered the pantheon of British comedy grotesques. Buffoonish, self-deluded, often mean and penny-pinching, and indifferent to his wife's desires unless forced to acknowledge them, Mr Khan is himself a carnivalesque figure.

However, this affords little space for other characters to develop. Mrs Khan (as she is invariably called) could have presented an opportunity to develop a subversive transformation of the stereotypes associated with older Asian women. Yet the role reprises the familiar sitcom tropes of the childlike husband and his patiently supportive and sensible wife. While the ostensible intention is to expose Mr Khan's patriarchal attitudes, this is not done in ways that genuinely constitute a Rabelaisian overturning of social norms or of masculine narrative centrality. Instead, Mr Khan's schemes, pratfalls and farcical endeavours lead the storylines, leaving Mrs Khan shoehorned into the role played by June Whitfield as the exasperated but tolerant wife of silly old Terry Scott in that most conventional of sitcoms, Terry and June (BBC, 1979-87). Citizen Khan does indeed clear a space for representations of British Asian identities that acknowledge their hybrid character, 
but it also recuperates Mr Khan into a Muslim version of Dad's Army's Captain Mainwaring and permits only limited comedic agency to his wife.

\section{Conclusion}

As we have seen, these representations of older Asian women have formed an interesting arc. While the confinement of such roles to the exotic has changed in important ways, it is still unusual to find characters who present as complex and contradictory. Moreover, as the cultural climate in Britain has become more polarised in the wake of the Brexit referendum in 2016, the opportunities afforded to actors of Asian heritage appear to have been pulled back towards highly reductive roles as 'radicalised' Muslims and their victimised families in crime dramas and thrillers supposedly torn from the headlines. Such texts not only contribute towards the potentially dangerous conflation of religious and cultural differences amongst British Asians, they inevitably offer little space for the kind of Rabelaisian rambunctiousness I have highlighted.

It would be a pity if the transgressive potential presented by these particular Aunties were to be recuperated or worse, entirely silenced by a resurgent fear of the other in British popular culture at a point when the legacy of Empire has just begun to be properly addressed. Such a legacy must contain the possibility of laughter as well as sobriety, and there can be few figures who embody such contradictory meanings in such universally subversive ways.

\section{References}


Abbas, Tahir. 2013. "'Last of the dinosaurs': Citizen Khan as institutionalisation of Pakistani stereotypes in British television comedy". South Asian Popular Culture 11(1): 85-90.

Are You Being Served? 1972 - 1985. Television Series. UK: BBC.

Arthurs, Jane. 1999. "Revolting Women: the Body in Comic Performance." In Women's Bodies: Discipline and Transgression, edited by Jane Arthurs and Jean Grimshaw, 137-164. London and New York: Cassell.

Aunties in 1919. https://www.pinterest.co.uk/pin/735283076637401515/ Accessed 05/03/19.

Aunty No 1. 1998. Film. Directed by Kiri Kumar. India: Lata Films.

Bakhtin, Mikhail. 1965. Rabelais and His World. London: Penguin.

Bend it Like Beckham. 2000. Film. Directed by Gurinder Chadha. UK: British Screen/Fox Searchlight.

Birds of a Feather. 1989 -1998, 2014 - 2017. Television Series. UK: BBC, ITV.

Black Narcissus. 1947. Film. Directed by Michael Powell, Emeric Pressburger. UK: UIP.

Bhaji on the Beach. 1993. Film. Directed by Gurinder Chadha. UK: FilmFour.

Bollywood Aunties and their various personas. https://www.movified.com/bollywoodaunties-and-their-various-personas Accessed 16/07/18 
Bourne, Stephen. 1998. Black in the British Frame: Black People in British Film and Television 1896-1996. London: Cassell.

Carry On Up the Khyber. 1968. Film. Directed by Gerald Thomas. UK: Rank.

Citizen Khan. 2012 -. Television Series. UK: BBC.

Chandha, Shalini. "Tandoori Nights 1985-87." BFI Screenonline. Accessed 07/03.19.

http://www.screenonline.org.uk/tv/id/529222/index.html

Chapman, James. 2012. "A short history of the Carry On films." In British Comedy Cinema, edited by I.Q. Hunter and Laraine Porter, 100-15. London and New York: Routledge.

Desai, Jigna. 2004. Beyond Bollywood: The Cultural Politics of South Asian Diasporic Film. New York and London: Routledge.

The Drum. 1938. Film. Directed by Zoltan Korda. UK: London Films.

Dyer, Richard. 1979. Stars. London: BFI.

East Enders. 1985 -. Television Series. UK: BBC.

East Is East. 1999. Film. Directed by Damien O'Donnell. UK: FilmFour. 
Elephant Boy. 1937. Film. Directed by Robert Flaherty, Zoltan Korda. UK: London Films.

Emig, R. 2010. "The Empire Tickles Back: Hybrid Humour (and its Problems) in Contemporary Asian-British Comedy." In Hybrid Humour: Comedy in Transcultural Perspectives, edited by G. Dunphy, and R. Emig, 169 - 195. Amsterdam and New York: Rodopi.

Gangsters. 1975, 1976-78. Television Series. UK: BBC.

Goodness, Gracious Me. 1998 - 2001, 2015. Television Series. UK: BBC.

Hallam, Julia. 2005. “Angels, battleaxes and good-time girls: cinema's images of nurses." In Signs of Life: Cinema and Medicine, edited by Graeme Harper and Andrew Moor, 105-19. London: Wallflower.

Heat and Dust. 1983. Film. Directed by James Ivory. UK/USA: Merchant Ivory Productions.

Hunt, Leon. 1998. British Low Culture: From Safari Suits to Sexploitation. London: Taylor and Francis.

Hum Aapke Hain Koun...! 1994. Film. Directed by Sooraj Barjatya. India: Rajshiri Productions.

Huq, Rupa. 2013. "Situating Citizen Khan: Shifting representations of Asians onscreen and the outrage industry in the social media age." South Asian Popular Culture 11 (1): 7783.

I'm British, But... 1989. Film. Directed by Gurinder Chadha. UK: BFI/Channel Four. 
It Ain't Half Hot Mum. 1974 - 81. Television Series. UK: BBC.

The Jewel in the Crown. 1984. Television Series. UK: Granada.

Jordan, Marion. 1983. "Carry on: follow that stereotype." In British Cinema History, edited by James Curran and Vincent Porter, 312-27. London: Weidenfeld \& Nicholson.

Kavoori, Anandam P. and Punathambekar, Aswin. 2008. "Introduction: Global Bollywood." In Global Bollywood, edited by Anandam P. Kavoori and Aswin Punathambekar, 1-14. New York and London: New York University Press.

Ken Hom's Chinese Cookery. 1984. Television Series. UK: BBC.

The Kumars at Number 42. 2001-6; 2014. Television Series. UK: BBC, Sky.

Last of the Summer Wine. 1973 - 2010. Television Series. UK: BBC.

Madhur Jaffrey's Indian Cookery. 1982. Television Series. UK: BBC.

Medhurst, Andy. 2007. A National Joke: Popular Comedy and English Cultural Traditions. London: Routledge. 
Mendes, Ana Christina. 2010. “Triangulating Birmingham, Blackpool, Bombay: Gurinder Chadha's Bhaji on the Beach." Anglo Saxonica 3 (1): 7-20.

Mendes, Ana Christina. 2018. "Surviving The Jungle Book: Trans-temporal Ventriloquism in Ian Iqbal Rashid's Surviving Sabu." Journal of British Cinema and Television 15 (4): 532-552.

Mercer, Kobena. 1990. "Black art and the burden of representation." Third Text 4 (10): 6478.

Mind Your Language. 1977-86. Television Series. UK: LWT.

My Beautiful Laundrette. 1985. Film. Directed by Stephen Frears. UK: Working Title/Channel Four Films.

Nai Zindagi, Naya Jeevan. 1968 -82. Television Series. UK: BBC.

NDTV 10 Annoying Things This Indian Aunty Says. http://www.ndtv.com/offbeat/10annoying-things-this-indian-aunty-says-577541 Accessed 03/12/16

Richards, Jeffrey. 1983. "British Imperial Cinema in the 1930s." in British Cinema History edited by James Curran and Vincent Porter, 245-271. London: Weidenfeld and Nicholson.

Rao, Shakuntala. 2007. "The Globalization of Bollywood: An Ethnography of Non-Elite Audiences in India." The Communication Review 10 (1): 57-76. 
Tandoori Nights. 1985-87. Television Series. UK: Channel 4.

Terry and June. 1979-87. Television Series. UK: BBC.

The Thief of Bagdad. 1940. Film. Directed by Michael Powell. UK: London films.

Tincknell, Estella. 2013. "Dowagers, Debs, Nuns and Babies: The Politics of Nostalgia and the

Older Woman in the British Sunday Night Television Serial." Journal of British Cinema and

Television 10 (4): 769-784.

Two Doors Down. 2013 -. Television Series. UK: BBC Scotland.

Young, Lola. 1996. Fear of the Dark: "Race", Gender and Sexuality in the Cinema. London

and New York: Routledge.

\footnotetext{
' Ground breaking works on race in the 1990s tended to focus on British representations of African Caribbean experiences and characters rather than Asian ones. These include Lola Young's Fear of the Dark: "Race", Gender and Sexuality in the Cinema (London and New York: Routledge, 1996) and Stephen Bourne's Black in the British Frame: Black People in British Film and Television 1896-1996 (London: Cassell, 1998).

ii See http://www.ndtv.com/offbeat/10-annoying-things-this-indian-aunty-says-577541 Accessed 03/12/19.

iii Hum Aapke Hain Koun...! (Sooraj Barjatya, 1994) is generally credited with the development of Bollywood towards a focus on the middle-class extended family, thus carving out space for numerous Auntie characters. iv See, for example the web page 'Discover ideas About Auntie 2019' which features a range of Bollywood Auntie figures: https://www.pinterest.co.uk/pin/735283076637401515/ Accessed March 2019.

$\checkmark$ See the movified website for the full range of Bollywood Auntie types: https://www.movified.com/bollywood-aunties-and-their-various-personas Accessed July 2018.

vi See, for example, Leon Hunt, British Low Culture: From Safari Suits to Sexploitation, London; Taylor and Francis, 1998; Hallam, Julia (2005), 'Angels, battleaxes and good-time girls: cinema's images of nurses', in Graeme Harper and Andrew Moor (eds), Signs of Life: Cinema and Medicine, London: Wallflower, pp. 105-19.

vii Bollywood Comedy Aunties are often overweight or physically grotesque, while Youtube contains numerous examples of Aunty parodies and send-ups, including drag queen 'Aunties'.

viii See Mendes, Ana Christina. 2018. "Surviving The Jungle Book: Trans-temporal Ventriloquism in lan Iqbal Rashid's Surviving Sabu", Journal of British Cinema and Television, 15 (4): 532-552.
} 
ix There are examples of British film stars of mixed race heritage such as Merle Oberon, who was a leading actress in the 1930s and 40s, most notably starring alongside Laurence Olivier in Wuthering Heights (1939). However, Oberon obscured her 'degrading' Indian and Maori background, claiming to have been born in Tasmania.

${ }^{x}$ The film also provided Sabu with a rare adult starring role.

xi For example, Gurinder Chadha comes herself from the Kenyan Asian diaspora whose origins were in the Punjab.

xii The Carry On series of cheaply made low comedy films began in 1958 and continued until 1972, each featuring broadly the same cast and including parodies of popular film genres and cycles. The films and their stars became a significant part of British comedy culture, partly through repeated television screenings.

xiii As referenced in the pioneering BBC documentary, It Ain't Half Racist, Mum (1979).

xiv Confusingly, commentary on Youtube clips of Mind Your Language, while difficult to locate geographically with any certainty, suggests that sub-continent audiences do not find the Asian stereotypes as offensive as might be expected: some comments from writers with Indian names (e.g. Singh, Kumar) refer approvingly to the grotesquely humorous depictions of 'Pakistani' men, perhaps reflecting cultural affinities/tensions across the sub-continent.

${ }^{x v}$ It also featured Saeed Jaffrey (who would become almost as ubiquitous as Zohra Segal - see below) as a trafficker of illegal immigrants.

xvi Zohra Segal deserves an entire essay to herself since there is not the scope here to examine her remarkable career as both an actress and dancer between 1935 and 2007. Segal died in 2014 at the age of 102; her 'second career' as the go-to actress to play feisty older Asian women in British films and TV dramas really began after she appeared in The Jewel in the Crown.

xvii See Tincknell, Estella, 'Dowagers, Debs, Nuns and Babies: The Politics of Nostalgia and the Older Woman in the British Sunday Night Television Serial', Journal of British Cinema and Television, Volume 10 Issue 4, 769784, ISSN 1743-4521 Available Online Oct 2013.

xviii The programme also helped to make the Pakistani-born but British educated Art Malik a television star.

${ }^{\text {xix }}$ For more on 'the burden of representation' see Kobena Mercer's 'Black art and the burden of representation', Third Text, Volume 4, No 10, 64-78.

${ }^{x x}$ It should be noted that Jaffrey began her cookery writing career in 1973 in New York, having moved there from London after studying at RADA. While the BBC series was her first foray into the British TV cookery genre, she was already an experienced food writer.

xxi Written by Farrukh Dhondy, an Indian-born veteran of British television comedy.

xxii And for a detailed reading of these issues see Chapter 5 of Jigna Desai's Beyond Bollywood: The Cultural Politics of South Asian Diasporic Film. New York and London: 2004.

xxiii Although it should be noted that the tall, blonde and thin Knightley's career has so far been considerably more glittering than that of the small, dark and Asian Nagra's.

xxiv The producer, Anil Gupta, was also of British Asian background.

${ }^{x x v}$ The song had originally been planned to feature in the Sellers-Loren vehicle, The Millionairess (1960) but was dropped from the film and then released independently, becoming a chart hit in the UK. xxvi Dyer's seminal book, Stars (London: BFI, 1979), includes an exploration of the ordinary/extraordinary dyad. xxvii The cultural boundaries of East is East's gender politics were set by the film's poster which decoratively foregrounds a young, white, blonde and mini-skirted female character posed suggestively against the main male protagonist, despite the fact that she plays no significant role in the narrative. 